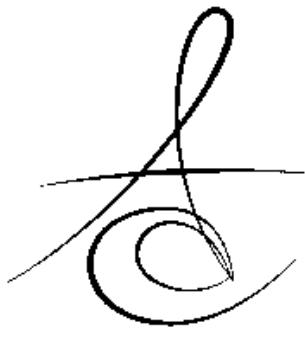

\section{ÇİĞNEMENİN NÖROFİZYOLOJİSİ VE GENEL MOTOR KONTROL İLE ETKİLEŞİMI}

\section{THE RELATIOONSHİP BETWEEN NEUROPHYSİOLOGY OF MASTICATION AND GENERAL MOTOR CONTROL}

Uz. Dr. Murat KAYABEKİR

Doç. Dr. Meltem TUNCER

Prof. Dr. Kemal S. TÜRKER

\title{
ABSTRACT
}

öz

Çene ve dişlerin nörofizyolojik mekanizmalarının anlaşılması, bireylerin ağız ve genel vücut sağlğının sürdürülmesine önemli katkılar sağlar. Çiğnemenin kontrolünde merkezi rol oynayan periferik reseptörlerin en önemlisi periyodontal mekanoreseptörlerdir. Bu mekanoreseptörler, ağız içi motor fonksiyonları düzenler ve bu fonksiyonların genel motor fonksiyonlarla ilişkisini kurar. Bu reseptörlerin şu fonksiyonları da ayrıca önemlidir: (1) Özgün duyusal donanımları sayesinde ağız ve diş sağlı̆ı̆ızı korurlar; (2) motor kontrolde esas olan reflekslerle etkileşim içine girerler; (3) kas-iskelet sistemi ve total vücut kuvvetine olumlu etkileri söz konusudur.

Anahtar Kelimeler: çiğneme, periyodontal mekanoreseptör, motor kontrol, vücut kuvveti

Çiğnemenin kontrolünde merkezi rol oynayan periferik reseptörler, ağız içi motor fonksiyonları düzenler ve genel motor fonksiyonlarla bağlantı kurar. Aslında ağız sağlığı ile genel vücut sağlığı arasındaki olumlu ilişkinin en temel mekanizmalarını içerir. Oral mekanoreseptörlerden özellikle periyodontal mekanoreseptörlerin fizyolojik mekanizmalarını anlaşılması ve ortaya konması gerçekten vücudun genel motor fonksiyonları ile ilişkisinin ipuçlarını yakalamamıza yardımcı olur.

\section{1. Çiğneme Reseptörleri}

1.1. Periyodontal Mekanoreseptörler

Periyodontal ligament, alveolar kemikteki diş köklerine yapışmışır. Başlangıçta sadece dişleri koru-
Understanding the role of the jaw and teeth in the control of mastication by the neurophysiological mechanisms provides an important contribution to the maintenance of oral and general health status of individuals. Peripheral receptors play a central role in the control of mastication and the most important of these are the periodontal mechanoreceptors. These receptors regulate intra-oral motor functions and these functions contribute to the general motor functions. Other than helping to crush food particles during chewing, these receptors also have the following functions: (1) They protect mouth and teeth with their special sensory properties; (2) they initiate reflexes that maintain smooth mastication; (3) they contribute to the general musculo-skeletal system and the total body strength.

Keywords: mastication, periodontal mechanoreceptors, motor control, body strength

yan ve destekleyen bir yapı olarak göze çarpsa da, aslında düşük eşik değere sahip mekanoreseptörlerce oldukça zengin, önemli bir duyusal organdır. ${ }^{1-3}$ Periyodontal destek dokular, çiğneme kaslarına ait nöral kontrol mekanizmalarında oldukça önemli rol oynarlar. Sanki çiğneme ile ilgili kasları ve onların hareketlerini yastıkla destekler gibi tamponlarlar, yani çene hareketleri için amortisör görevi görürler. ${ }^{4-6}$

\subsection{1. İnnervasyonu}

Periyodontal mekanoreseptörleri innerve eden sinir liflerine ait çoğunun hücre gövdesi, trigeminal (Gasser) gangliyonda ve daha az sayıda trigeminal mesensefalik nukleusta bulunmaktadır. Dişlerin

*Bölge Eğitim ve Araştırma Hastanesi, Uyku Bozuklukları Merkezi Elektrofizyoloji Laboratuvarı

${ }^{* *}$ Hacettepe Üniversitesi Tıp Fakültesi Fizyoloji AD.

${ }^{* * *}$ Koç Üniversitesi Tıp Fakültesi Fizyoloji AD. 
mekanik uyarıya karşı cevabının spinal trigeminal nukleusun rostral parçası ve supratrigeminal internöronlar aracılı̆ı̆ ile gerçekleştiği gösterilmiştir.?

\subsubsection{Fonksiyonel Özellikleri}

Dişlerimiz, çiğneme ve ısırma esnasında yiyecekleri, karmaşık ve farklı sürelerde oluşan güç kalıplarının etkisi altında tutmaktadır. Bir güç bir dişe uygulandığında, o diş, yuvasında belli belirsiz hafifçe hareket eder. Bu hareket periyodontal ligamentin gerilmesi ve stresine neden olmaktadır. ${ }^{6,7}$ Dişlere uygulanan güçlere cevap veren periyodontal mekanoreseptörlere ait özellikleri genel olarak şöyle sıralayabiliriz:

(1) Dişteki birkaç mikronluk yerinden oynamayı fark eder, bazen de daha az duyarlı olur ve sadece daha büyük güçlere yanıt verir.

(2) Özellikle belli bir yönde gelen güçlere karşı maksimum cevap veren sinir liflerinde olduğu gibi, yöne bağlı duyarlılık gösterir.

(3) Sabit bir uyarı uygulandığında devamlı deşarj üretir ve yavaş adapte olur ayrıca meydana gelen sadece birkaç impulsla aniden stimüle edildiğinde daha hızlı adapte olur.

(4) Bazılarının çok hızı adaptasyon üniteleri vardır, çok hızlı bir uyarı uygulanmadığı sürece cevap veremez.

(5) Bazıları spesifik yönlerde uygulanan artan veya azalan güçlere sabit bir deşarj sağlarlar ve bunların çok yavaş adaptasyon ünitelerinin olduğundan bahsedilmektedir.

Normalden daha fazla fonksiyonel güç ortaya çıktığında, periyodontal mekanoreseptör aktivitesinde artış ile sonuçlanan, çiğneme kası aktivitesinde refleks değişiklikler meydana gelir. ${ }^{6-9}$ Aslında periyodontal reseptörlerin hepsi aynı özelliklere sahip olup, kökteki konumları nedeni ile bazı uyarıları zayıf ya da kuvvetli olarak alırlar ve zayıf olarak aldıklarında daha az aksiyon potansiyeli oluşturarak ve çabuk adaptasyon göstererek tepki verirler. Örneğin, bir reseptör kökün ucuna yakın bir yerde bulunuyor ise, dikine gelen kuvvetlerce daha kolay uyarilır, ancak yatay kuvvetlerle çok az uyarııı. ${ }^{9,10}$

\subsection{Kas İğciği:}

Orofasyal kasların kas iğcikleri, işlev ve yapısal olarak genel vücut kaslarının kas iğciklerine benzemektedir. Kas iğcikleri, yer çekimi etkisine karşı değişmeyen bir çene postürünün sürdürülmesini sağlayan ve planlanan gerçek mandibular hareketlerin ortaya çıkarılmasında meydana gelebilecek koordinas- yon hatalarını azaltan ya da ilgili ayarlamaları yapan bir sensör olarak karşımıza çıkmaktadır. Örneğin; dişler arasında bir fındık kırıldığında, fındık kırııır kırılmaz, güçlü elavator kas kontraksiyonu ani bir sönme ile sonuçlanır. Elavator kasların ani kısalması a motor nöronların aktivitesinde ard arda azalmalar neticesinde, kas iğciği deşarjında bir azalmaya neden olur. Aslında, Isıırıken veya bir fındığı kırarken dişler arasındaki mesafe ve fındığın çapına göre çiğneme hareketleri ortaya çıkmaktadır. Normal şartlar altında dişler arasında 100 kg'ın üzerinde güç oluşabilir, ancak ani bir direnç ile karşı karşıya kalındığında, nadir de olsa dişler kırılabilir. Bu yüzden mandibular elavatorların kas iğcikleri, diğer nöronlarla bağlantılarını kesmeksizin diğer kas iğciklerini de monitörize ederler. ${ }^{9-11}$

\subsection{Golgi Tendon Organı:}

Kas iğciğindeki paralel yerleşimin aksine, kas ile olan seri bağlantısı nedeni ile golgi tendon organı kasın gerilmesi veya kasın kasılması ile aktive edilir. Bununla birlikte kasın kasılması, gerilmesinden çok daha etkin bir uyarandır. Gerçek uyaran golgi tendon organını bulunduran tendonda meydana gelen kuvvettir. Bu nedenle golgi tendon organı, kasın boyunu ve boydaki değişme hızını kodlayan kas iğciğinden farklı olarak, 'kuvveti' iletir. Hayvan veya insan çene kaslarında, golgi tendon organlarının var olduğu sınırlı kanıtlarla ortaya konmuştur. Çok az sayıda golgi tendon organı, masseter ve temporal kasların derininde ve bu kasların mandibulaya yapışığı noktada yerleşmiştir. Buna rağmen, golgi tendon organının çiğneme sistemindeki fonksiyonel önemi hakkında bilgi bulunmamaktadır. Dişler çıkmadan önce golgi tendon organının görev yaptığı ve sonradan kaybolduğu belirtilmekte olup, dişler çıkınca periyodontal mekanoreseptörler aynı golgi tendon organının yapacağı gibi kasslan kasları gevşetmektedir (periyodontal refleks). ${ }^{11-14}$

\subsection{Temporomandibular Eklem}

\section{Reseptörleri:}

Mandibulanın yani çenenin pozisyonunun algılanmasından sorumludur. Temporomandibular eklem reseptörleri genellikle vücuttaki diğer eklem reseptörlerine benzemektedir. Genellikle eklem kapsülünün her tarafına yayılmış olan çıplak sinir uçlarıdır. Bunun yanında Ruffini, Paccini ve Golgi reseptörleri de eklem kapsülünün lateral parçası ve lateral ligamentinde bulunmaktadır. ${ }^{15}$ Eklem ligamentleri ve kapsülleri, çok sayıda yavaş adaptasyon gösteren mekanoreseptörler 
içermektedir. Bu mekanoreseptörler, kapsül ve ligamentin bükülmesi veya gerilmesine cevap vermektedirler. Ligamentlerdeki yavaş adaptasyon gösteren cevaplar Golgi tendon organ tipi sonlanmalar tarafindan iletilirken, kapsüldeki yavaş adaptasyon gösteren cevaplar Ruffini tipi sonlanmalardan kaynaklanmaktadır. Temporamandibular eklem, sadece sahip olduğu kondilin rotasyon hareketine değil, aynı zamanda bütünleşmiş çene hareketlerinin oluşmasındaki fonksiyonundan dolayı vücuttaki pek çok eklemden ayrımaktadır. Temporamandibular eklemin afferent innervasyonunun hücre gövdeleri, trigeminal gangliyonun posterolateral parçasında bulunmaktadır. Bu nöronların merkezi bağlantıları ise duyusal trigeminal nukleusun tüm kısımlarına dağıımışır. $7,15,16$

\section{2. Çiğnemenin Kontrolü}

2.1. Orofasyal Bölgeye Ait Motor ve

\section{Duyusal Sistemlerin Etkileşimi}

Çiğneme, konuşma ve oluşan yüz ifadeleri insanların gerçekleştirdiği en karmaşık motor davranışlar arasında yer alır. Çiğneme hareketleri kompleks olmakla beraber, gayet iyi koordinasyon sağlayan pek çok nöromusküler olayı içermektedir. Bu nöromusküler olaylar sadece mandibulanın aşağıya ve yukarıya hareketlerinin meydana gelmesini değil, aynı zamanda dişlerin, kesin ve doğru bir hizada karşı karşıya gelmesini sağlamaktadır. ${ }^{12-17}$

Çene, çok sert gıdaları ezerken, yüzlerce Newton büyüklüğünde kuvvetlerin meydana gelmesine neden olmaktadır. Bu kuvvetler oluşurken aynı zamanda dişler arasındaki oklüzyon mesafeleri korunup, dişlerin hemen bitişiğindeki yumuşak dokuların da zarar görmesi engellenmektedir. Beyin devamlı olarak meydana gelen bu süreçleri takip eder. Ağız içindeki yiyecek maddesine ait fiziksel parçalar ve onların lokalizasyonları, yanaklar, dudaklar, dil ve çene hakkındaki bütün bilgiler merkezi sinir sistemi tarafindan hesaba katılmaktadır. Bu bilgilenme orofasyal dokulardaki özel reseptörler aracıı̆ı̆ı ile sağlanmaktadır. ${ }^{15-17}$

Dilin motor becerilerinin ve kas tonusunun azalmasının, çiğneme etkinliğini azaltabileceği belirtilmiştir. Çiğneme performansı ise, dil motor becerileri ile uyumlu olarak tam protez kullanan hastalarda en düşük tesbit edilmiştir. ${ }^{18}$

Vücudun hiçbir bölgesinde bu kadar gelişmiş, dokunma duyusunun detaylarını bu kadar emsalsizce algılayan ve ağız içinde sürekli olarak gelişimin sağlandığı bir başka somatik-duyusal sistem daha bulunmamaktadır. Bu kontrol o derecedir ki, ağzı- mızdaki bir yiyeceğin sertliğindeki değişmeye uygun olarak her ısırışımızda ısırma kuvveti otomatik olarak değişmektedir. Köprüleri ya da protezleri ile yemek yiyenlerde ise bu otomatik değişikliğe rastlanmaz. ${ }^{12-19}$

\section{2. İnsan Çene Kası Motor Nöronlarının Aktivasyonu:}

Çene kası motor nöronları üç kaynak tarafından aktive edilir: (1) Çiğnemenin başlaması ve durmasını sağlayan, beklenen ve geribildirime bağlı önceden programlanmış hareket kalıplarını doğuran motor korteks; (2) çene kaslarına ait temel ritmik aktiviteyi sağlayan merkezi kalıp üreteçleri; (3) son olarak en güçlü, en önemli kaynak ise periferik geribildirimdir. ${ }^{19}$

\subsubsection{Motor Korteks}

Çiğnemenin başlaması ve durmasını sağlayan beklenen ve geri bildirime bağlı önceden programlanmış hareket kalıplarını oluşturur. Motor korteks, çene kası motor nöronlarına direkt ve indirekt uyarılar gönderir. İnsanlarda transkraniyal tekniklerin kullanımı ile bu etkiler araştırlabilmektedir. Korteksten başlangııını alan yollar, çiğnemenin bilinçli olarak başlaması ve sonlanması için kullanı.ır. ${ }^{19,} 20$

\subsubsection{Merkezi Kalıp Üreteçleri}

Hayvan deneyleri merkezi kalıp üreteçleri diye bilinen, bir grup hücre tarafından üretilen çiğneme için bir ritim üreticisinin varlığını kanıtlamıştır. Merkezi kalıp üreteçleri; N. Trigeminus (V. kafa çifti) ve N. Facialis (VII. kafa çifti)'in motor çekirdekleri arasındadır. ${ }^{20}$

1971'de Delow ve Lund; çiğneme bir kere başlayınca, beyin sapındaki bir yapının çene açma ve kapama kaslarına alternatif olarak değişen impulslar gönderdiğini keşfetmişlerdir. Merkezi kalıp üreteçleri çiğnemenin açılma fazı boyunca açıc motor nöronlardaki eksitasyonla eş zamanlı olarak kapatıcı motor nöronlardaki inhibisyonun meydana gelmesini indüklerken, kapanma fazı boyunca ise kapatıcı motor nöronlarda bir eksitasyonun meydana gelmesini indüklemektedir. Merkezi kalıp üreteçlerinin sırası ile açıcı ve kapayıcı motor nöronları aktive etmesi çiğnemenin temel ritmini ayarlıyor olmasına rağmen, bu sürecin kontrolü büyük oranda duyusal geribildirim bağımlıdır (Şekil 1). Merkezi kalıp üreteçleri üst beyin merkezlerinden ve duyusal reseptörlerden bilgi almak- tadır. Bu bilgi akışında dudak ve oral mukozadaki do- kunma reseptörlerinin, çene kapanma kaslarındaki kas iğciklerinin ve diş kökleri etrafındaki periyodontal ligamentlerdeki özelleşmiş mekanoreseptörlerin önemi büyüktür. ${ }^{21,22}$ 


\subsubsection{Periferik Geri Bildirim}

Dişe uygulanan kuvvetlere yanıt veren periyodontal mekanoreseptörler, çiğnemenin kontrol mekanizmalarının kavşak noktasını oluşturmaktadır. Merkezi kalıp üretecine duyusal periferik geri bildirimin sağlanmasında önemli yeri olan diğer yapılar ise; kas iğcikleri ve temporamandibular eklem reseptörleridir (Şekil 1). Çene hareketleriyle diş ve etrafındaki dokular uyarıldığında, periyodontal mekanoreseptörlere ek olarak çenenin pozisyonunun algılanmasından sorumlu kas iğciği ve temporamandibular eklem reseptörleri uyarılmaktadır. ${ }^{23,24}$

Tam protez kullanan bireylerde artan yaş ve oral duyu fonksiyonun azalması ile çiğneme performansının azalması arasında ilişki olduğu belirtilmiştir. Mantecchini ve ark., yaşlı bireylerde oral stereognosis yeteneğinin daha kötü olduğunu rapor etmiştir. ${ }^{25}$

\section{Ağız İçi Motor-Duyusal Sistem ile}

\section{Genel Motor Fonksiyonlar Arasındaki Bağlantı:}

Az sayıda makalede ağızdaki motor işlevler ile vücudun diğer bölümlerinin motor işlevleri arasındaki bağlantı gösterilmeye çalışıımıştır. İstemli diş sıkmanın kas reflekslerinin gücünü artırdığı gösterilmiş, reflekslerin güçlenmesinin duruşun daha dengeli olmasına katkıda bulunabileceği öne sürülmüştür. ${ }^{24-26}$ Diş sıkmanın kas kasılma kuvvetini nasıl etkilediği konusu hakkında çok az sayıda çalışma vardır. Bunlardan birinde diş sıkmanın triceps surae kasında bütünleşmiş EMG genliğini ve maksimum kasılma kuvvetini artırdığını göstermiştir. ${ }^{26}$ Güç isteyen, kas kuvveti gerektiren durumlarla karşılaştığımızda gücümüzü uygularken çoğu kez farkına bile varmadan dişlerimizi sıkarız. $\mathrm{Bu}$ durum pek çok insan tarafından ağır bir yükü kaldırmaya çalışırken tecrübe edilmiştir. Yine özellikle kontak sporlar (boks, güreş, basketbol, voleybol vb.)' la uğraşanların, oluşturmaya çalıştığı güç esnasında dişlerini nasıl sıktığı pek çoğumuzun gözlemidir. Kontak sporlarla uğraşanlar ve oyun çağı çocuklarında görülen, alt ve üst dişlerin çarpması ile meydana gelen travmalar, diş ve çene kırıkları, ısırmaya bağı meydana gelen dil ve yanak yaralanmaları, kask ve ağız koruyucu kullanmanın önemine işaret etmektedir. Tüm bu gözlemler, ağızdaki motor işlevlerle, vücut dengesi ve motor fonksiyonlar arasındaki bağlantıyı tartışmaya sebep olmuştur. Bu yüzden gücü oluşturan motor kuvvet ile ağız içi motor-duyusal sistemin etkileşimi araştırmacılar tarafından sorgulanmıştır. ${ }^{27-29}$

Isırma kuvveti yaş, cinsiyet ve vücut kitlesi ile de ilişkilidir. Maksimum ısırma kuvvetinin yaşla ve büyümeyle arttığı, 20 ile 40-50 yaş arasında sabit kaldığı ve daha sonra azaldığı bildirilmiştir. Erkeklerde de bayanlara göre fazla olduğu gösterilmiştir. Isırma kuvvetinin fasial morfoloji ile de ilişkisi bulunmaktadır. Vertikal yüz boyutları, anterior ve posterior yüz yüksekliği, mandibular inklinasyon ve gonial açı arttıkça ısırma kuvveti azalmaktadır. Gerçekten, çiğneme performansını yeterli düzeyde yerine getiremeyen bireyler, psikolojik ve fizyolojik yönden etkilenmektedir. ${ }^{30-32}$

Oral inflamasyonlar, hareket yetersizliği riskini artıran kas kuvveti kayıplarına eşlik edebilmektedir. Geçirilmiş oral enfeksiyonlara bağlı meydana gelen periyodontitisler başta olmak üzere, eksik dişlerin varlığı, diş eti kanamaları ve var olan diş taşları gibi ağız içi rahatsızlıklarının kas kuvvetinde azalmaya yol açtığı bilinmektedir. ${ }^{33,34}$

Dişlerin sıkılması ile motor korteksin yüz bölümü istemli olarak aktive olmaktadır. Bu aktivasyonun yüz bölgesinden el ve bacak kortikal temsil alanlarına yayılabildiği ve medulla spinalisde sonlanan inen kolaylaştırıcı lifleri uyarabildiği ileri sürülmüştür. İstemli diş sıkma, derin tendon reflekslerinin artışına yol açmaktadır. Buradan yola çıkılarak yapılan çalışmalar sonucunda, primer motor korteksteki el motor alanının uyarılabilirliğinin istemli diş sıkma ile değiştiği gösterilmiştir. ${ }^{35-37}$

Ancak tüm bu çalışmalara rağmen total kuvvetin bir göstergesi olan el sıkma kuvveti ile oral bölge arasındaki etkileşimlere neden olan fizyolojik mekanizmaların temelleri hala açıklanmaya çalışılmaktadır.

\section{Sonuç}

Dişleri ve etrafındaki reseptörleri sadece gıda öğütücüleri olarak göremeyiz. Özgün duyusal donanımları sayesinde ağız sağlığımızı korurlar, motor kontrolde esas olan reflekslerle etkileşim içine girerler, kas iskelet sistemi ve total vücut kuvvetine olumlu etkileri söz konusudur. Ağız ve diş sağlığı yaşamın her döneminde genel vücut sağlığı ile etkileşim içindedir. İleri yaşlara ne kadar az oral inflamasyon ve ne kadar fazla kendine ait diş sayısı varlığı ile girilirse yaşıılık dönemine ait fiziksel aktivite imkânı o kadar iyi olmaktadır. Sağlıklı bir hareket sistemi için diş hekimleri aracılığı ile ağız içi patolojilerinin erken teşhis ve tedavisi gerekmektedir. Sonuçta ağız ve genel vücut sağlığının bir bütün olduğu bilinci her yaşta, özellikle ileri yaşlarda hareket kabiliyeti yüksek, sağlıklı bireylerin ortaya çıkması açısından önemlidir. 


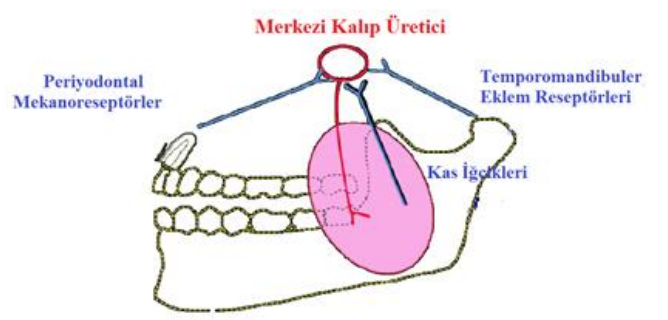

Şekil 1. Çiğnemenin kontrolünde periferik geri bildirimin önemi. Merkezi kalıp üretecine periferik reseptörlerden (periyodontal mekanoreseptörer, temporomandibular eklem reseptörleri ve kas iğciği) gelen geri bildirim sinyalleri şematik olarak gösterilmektedir.

\section{KAYNAKLAR}

1. Bradley RM. Essentials of Oral Physiology. 1 ed. St Louis; Mosby: 1995; 51-80.

2. Dessem D, Iyadurai OD, Taylor A. The role of periodontal receptors in the jaw-opening reflex in the cat. J. Physiol 1988; 406: 315-30.

3. Miles TS. Clinical Oral Physiology. 1 ed. Copenhagen; Quintessence: 2004; 219-43.

4. Dessem D. Sensorimotor responses evoked by tooth displacement. 'Brain and Oral functions' 1 ed. Amsterdam; Elsevier: 1995; 39-47.

5. Finan DS, Barlow SM. Intrinsic dynamics and mechanosensory modulation of non-nutritive sucking in human infants. Early Hum. Dev 1998; 52: 181-97.

6. Carels $C$, vanSteenberghe $D$. The influence of jaw position and antagonistic tooth relations on the appearance of a short latency excitatory reflex in the human masseter muscles following mechanical tooth stimulation. Arch Oral Biol 1986; 769-74.

7. Lavelle CLB. Applied Oral Physiology. 2 ed Bristol; Butterworths \& Co: 1988; 12-25.

8. Türker KS. Reflex control of jaw muscles. Oral Biol Med 2002; 13(1): 85-104.

9. Linden RWA, Millar BJ. The response characteristics of mechanoreceptors related to their position in the cat canine periodontal ligament. Arch Oral Biol 1988; 33: 51-6.

10. Türker KS, Brodin P, Miles TS. Reflex responses of motor units in human masseter muscle to mechanical stimulation of a tooth. Exp Brain Res 1994; 100: 307-15.

11. Türker KS, Sowman PF, Tuncer M, Tucker KJ. The role of periodontal mechanoreceptors in mastication. Arch Oral Biol 2007; 52: 361-4.
12. Scutter SD, Türker KS. Muscle spindle afferent input to motoneurons in human masseter. J. Neurophysiol 1999; 82: 505-7.

13. Trulsson M, Essick GK. Clinical Oral Physiology. 1 ed. Copenhagen; Quintessence: 2004; 165-97.

14. Watras JM. Physiology. 6 ed. Philadelphia; Mosby: 2008; 233-55.

15. Costanzo LS. Physiology. 3 ed Philadelphia; Elsevier: 2006; 97-101.

16. Brodin P, Türker KS, Miles TS. Mechanoreceptors around the tooth evoke inhibitory and excitatory reflexes in the human masseter muscle. J. Physiol 1993; 464: 711-23.

17. Haraldson T. Comparisons of chewing patterns in patients with bridges supported on osseointegrated implants and subjects with natural dentitions. Acta Odontol Scand 1983; 41(4): 203-8.

18. Özdemir Ö, Akören C. Chewing efficiency of complete denture. J Dent Fac Atatürk Uni 2010; 3: 60-9.

19. Cruccu G, Berardelli A, Inghilleri M, Manfredi $M$. Functional organisation of the trigeminal motor system in man. Brain 1989; 112: 1333-50.

20. Gooden BR, Ridding MC, Miles TS, Nordstrom MA, Thompson PD. Bilateral cortical control of the human anterior digastric muscles. Exp Brain Res 1999; 129: 582-91.

21. Dellow PG, Lund JP. Evidence for central timing of rhythmical mastication. J. Physiol 1971; 215:1-13.

22. Carels C, vanSteenberghe D. Do periodontal mechanoreceptors mediate the short latency excitatory reflex in human masseter muscle? Electromyography Clin Neurophysiol 1985; 25: 261-70.

23. Brodin $\mathrm{P}$, Türker KS. Evocation of either excitatory or inhibitory reflex responses in human masseter muscle by electrical stimulation of the lip at varying intensities. Arch Oral Biol 1994; 39: 701-6.

24. Linden RWA, Taylor A. Neurophysiology of Jawsand Teeth. 1 ed. London; Macmillan: 1990; 52-95.

25. Hirano K, Hirano S, Hayakawa I. The role of oral sensorimotor function in masticatory ability. J Oral Rehabil 2004; 31: 199-205.

26. Tuncer $M$, Tucker KJ, Türker KS. Influence of tooth clench on the soleus H-reflex. Arch Oral Biol 2007; 52: 374-6. 
27. Sasaki $Y$, Ueno T, Taniguchi H, Ohyama T. Effect of teeth clenching on isometric and isokinetic strength of ankle plantar flexion. J Med Dent Sci 1998; 45: 29-37.

28. Furubayashi $T$, Sugawara $K$, Kasai $T$, Hayashi A, Hanajima R, Shiio Y, Iwata NK, Ugawa Y. Remote effects of self-paced teeth clenching on the excitability of hand motor area. Exp Brain Res 2003; 148: 261-5.

29. Hatch JP, Shinkai RS, Sakai S, Rugh JD, Paunovich ED. Determinants of masticatory performance in dentate adults. Arch Oral Biol 2001; 46: 641-8.

30. Ingervall $B$, Minder $C$. Correlation between maximum bite force and facial morphology in children . Angle Orthod 1997; 67: 415-24.

31. Öz A. Z, Ciğer S. Masticatory functions and malocculusion. J Dent Fac Atatürk Uni 2013; 23: 436-40.

32. Throckmorton GS. Functional deficits in orthognathic surgery patients. Semin Orthod 2006; 12: 127-37.

33. Ranalli DN, Demas PN. Orofacial injuries from sport: preventive measures for sports medicine. J. Sports Med 2002; 32: 409-18.

34. Visser M, Pahor M, Taaffe DR. Relationship of interleukin-6 and tumor necrosis factor-alpha with muscle mass and muscle strength in elderly men and women: The Health ABC Study. J Gerontol A Biol Sci Med Sci 2002; 57: 326-32.

35. Sugawara K, Furubayashi T, Takahashi M, Ni Z, Ugawa $Y$, Kasai T. Remote effects of voluntary teeth clenching on excitability changes of the human hand motor area. Neuroscı Lett 2005; 377: 25-30.

36. Takahashi M, Ni Z, Yamashita T. at al. Excitability changes of human hand motor area dependent on afferent inputs induced by different motor tasks. Exp Brain Res 2004; 158: 527-32.

37. Boroojerdi B, Battaglia F, Muellbacher W, Cohen LG. Voluntary teeth clenching facilitates human motor system excitability. J Clin Neurophysiol 2000; 111: 988-93.

\author{
Yazışma Adresi \\ Dr. Murat KAYABEKİR \\ Atatürk Üniversitesi Lojmanları. \\ 29-2, 25240 ERZURUM \\ e-mail:kayabekirmurat@gmail.com
}

